\title{
Tetramethylammonium hydroxide thermochemolysis for the analysis of cellulose and free carbohydrates in a peatbog
}

\author{
Céline Estournel-Pelardy ${ }^{\mathrm{a}}$, Frédéric Delarue ${ }^{\mathrm{b}}$, Laurent Grasset $^{\mathrm{a}^{*}}$, Fatima Laggoun-Défarge $^{\mathrm{b}}$, \\ André Amblès ${ }^{\mathrm{a}}$ \\ ${ }^{a}$ Université de Poitiers, CNRS, Laboratoire de Synthèse et de Réactivité des Substances \\ Naturelles - UMR 6514, 4 rue M. Brunet, 86022 Poitiers cedex, France. \\ ${ }^{\mathrm{b}}$ Université d'Orléans, Université François Rabelais - Tours, CNRS/INSU. Institut des \\ Sciences de la Terre d'Orléans - UMR 6113. Campus Géosciences. 1A rue de la Férollerie, \\ 45071 Orléans cedex 2, France. \\ E-mail: laurent.grasset@univ-poitiers.fr
}

\begin{abstract}
We have compared TMAH thermochemolysis with the classical method using acid hydrolysis for carbohydrates analysis in a peat core. Even if TMAH thermochemolysis does not analyse hemicellulosic carbohydrates and discriminate each individual carbohydrate sensu stricto, it allows the analysis of a cellulose pool hidden to acid hydrolysis and the specific analysis of free and terminal carbohydrates. Simple direct comparisons of thermochemolysis data with data generated from acid hydrolysis cannot be done because of the different mechanisms involved in each process. TMAH thermochemolysis must be viewed and used as a pertinent and complementary method for the analysis of carbohydrates protected and trapped by the organic matter in complex environmental systems.
\end{abstract}

\section{Introduction}

Because of their ubiquity and abundance, carbohydrates are potentially useful compounds in elucidating sources, processes and pathways of biologically important organic materials in natural environments.

Acid hydrolysis is currently used to liberate carbohydrates from soils. It involves acid hydrolysis and purification before their analysis by liquid chromatography or by gas chromatography after derivatization. Recommended procedures either use $\mathrm{H}_{2} \mathrm{SO}_{4}$ [1-6], $\mathrm{HCl}$ $[1,6-8]$ or TFA [1, 9-10] to cleave glycosidic bonds of polysaccharides yielding sugar monomers. These methods can be applied to a wide range of soil samples and are easy to perform but yet time-consuming.

Tetramethylammonium hydroxide (TMAH) is the most common reagent used for thermochemolysis (more than $90 \%$ of published thermochemolysis applications have used 
TMAH [11]). It is used for the analysis of complex and intractable samples such as soils and sediments. For that kind of samples, TMAH thermochemolysis provides useful information simultaneously on a wide range of compounds related to lipids, lignins, tannins, proteins and carbohydrates markers. Due to its capability to cleave common ester and ether bonds and to methylate acidic functional groups, TMAH thermochemolysis allows also the analyses of compounds entrapped in macromolecular network [12].

However, few studies have identified these products in soil samples [13-14]. It could be partly due to the relative poor sensitivity of TMAH thermochemolysis to carbohydrates both at high temperature (up to $\left.600^{\circ} \mathrm{C}\right)[15-16]$ or with extended reaction time $\left(250^{\circ} \mathrm{C}\right.$ during 30 min in sealed tube) [17].

On the other hand, several studies have shown that TMAH thermochemolysis of individual sugars releases, beside products formed by recombination of previously cleaved fragments, 3-deoxyaldonic acids methyl esters resulting from the isomerisation of the C-2 position and dehydration of the C-3 position. These products have conserved their original conformation at the C-4 and C-5 positions [13, 18-19]. As a consequence, aldohexoses such as glucose, mannose and allose give identical 3-deoxyaldonic acids methyl esters but different ones from their C-4 epimers (i.e. galactose, gulose and idose). In the same way, the 6deoxyhexoses, fucose and rhamnose (the C-4 epimer of fucose), give different saccharinic acids methyl esters. For the same reason, aldopentoses (xylose, arabinose, ribose and lyxose) give the same saccharinic acid methyl esters (Fig. 1). The methylated forms of these saccharinic products have mass spectra with $\mathrm{m} / \mathrm{z}, 129$ as base peak (for the interpretation of the electron impact MS fragmentation of permethylated saccharinic acids see Fabbri and Helleur (1999) [13] and Bleton et al. (1996) [20]). Furthermore, although their mass spectra present no evident differences, they present different chromatographic behaviour with different retention times in gas chromatography. Moreover, TMAH thermochemolysis of cellulose produces a specific epimeric pair of methylated isosaccharinic acids producing specific ions in EI mass spectroscopy (i.e. $\mathrm{m} / \mathrm{z}$, 173) [13]. Then, to detect monosaccharides and glycosidic units from cellulose with TMAH thermochemolysis, single ion monitoring at m/z 129 and 173 can be used to reveal their presence in complex materials.

Soil organic matter is composed of more or less altered and inherited biochemical compounds such as hemicellulose, cellulose and microbial sugars (i.e. mainly exopolysaccharides). Depending on organic matter sources and degradation, carbohydrate monomers exhibit distinctive composition patterns. Ombrotrophic peat bogs are covered mainly by Sphagnum spp. with Eriophorum as the dominant vascular species. Cyperaceae are 
rich in xylose (one of the most abundant aldopentoses in living kingdom) [8, 21] as well as in arabinose [22-24]. Conversely, galactose, mannose and rhamnose are adequate indicators for mosses, in particular Sphagnum spp. [22, 25]. In addition, fucose could be considered as a microbial marker in peat bogs [22].

At $400^{\circ} \mathrm{C}$, a recent study has shown that the identification of carbohydrates derivatives in soil samples is possible with TMAH thermochemolysis [14]. In addition, TMAH thermochemolysis can be applied to precise and large quantities of material (up to $1 \mathrm{~g}$ ) since an off-line preparative technique was developed [12].

Samples collected at different depths of a peat core were submitted to TMAH thermochemolysis.

Under the same thermochemolysis conditions, cellulose and the most abundant monosaccharides encountered in peat bog were submitted to thermochemolysis allowing their assignment among the peat samples products based both on the mass spectra and on the retention times in gas chromatography of their thermochemolysis derivatives. Despite unavoidable matrix effects, this off-line preparative thermochemolysis also allows a semiquantification of thermochemolysis products when known quantities of standards were analysed in the same conditions than the studied complex samples.

Results were compared with those obtained using a classical method for carbohydrates analyses (acid hydrolysis with $\mathrm{H}_{2} \mathrm{SO}_{4}$ ) to have insight on the capability of TMAH thermochemolysis for the carbohydrate analyses in soils and sediments.

\section{Materials and methods}

\subsection{Chemicals}

Aldopentoses (D-xylose, L-arabinose, D-ribose), aldohexoses (D-glucose, D-mannose, Dgalactose), deoxyhexoses (L-rhamnose, L-fucose), cellulose, deoxy-6-glucose, $\mathrm{H}_{2} \mathrm{SO}_{4}, \mathrm{CaCO}_{3}$ $\mathrm{CH}_{3} \mathrm{OH}, \mathrm{CH}_{2} \mathrm{Cl}_{2}, \mathrm{LiClO}_{4}$ and TMAH were purchased from Sigma-Aldrich (St Louis, USA) and BSTFA+TMCS (99:1) from Supelco (Bellefonte, USA).

\subsection{Peat samples}


Samples were collected in June 2008 at the open bog part of an undisturbed Sphagnumdominated mire in the Jura Mountains (Le Forbonnet peatland, France), which has been described in detail [26]. The site is protected by the EU Habitat Directive of Natura 2000 and has been classified as a Region Natural Reserve for more than $20 \mathrm{yr}$. Annual precipitation is about 1300-1500 mm per year, with a mean annual air temperature of 7-8 ${ }^{\circ} \mathrm{C}$. Samples were collected at different depths: (i) two samples were collected in the upper oxic part (acrotelm), (ii) two in the water table zone (mesotelm) and (iii) two in the anoxic part (catotelm) (Fig. 2). They were air dried $\left(40^{\circ} \mathrm{C}\right)$, finely ground and stored at $-20^{\circ} \mathrm{C}$ before further analysis.

\subsection{Carbohydrate analysis by hot water extraction and $\mathrm{H}_{2} \mathrm{SO}_{4}$ hydrolysis}

The detailed $\mathrm{H}_{2} \mathrm{SO}_{4}$ hydrolysis method has been described elsewhere [22]. The analysis is carried out in two experiments. The first operating procedure for total sugar analysis can be summarized as follows: $1 \mathrm{ml}$ of $\mathrm{H}_{2} \mathrm{SO}_{4}(12 \mathrm{M})$ was added to 20 to $30 \mathrm{mg}$ of dry peat in a Pyrex ${ }^{\circledR}$ test tube. After $16 \mathrm{~h}$ at room temperature, the samples were diluted with $9 \mathrm{ml}$ of $\mathrm{H}_{2} \mathrm{O}$ to a $1.2 \mathrm{M}$ concentration in $\mathrm{H}_{2} \mathrm{SO}_{4}$. The tube was tightly closed under vacuum and heated at $100^{\circ} \mathrm{C}$ for $4 \mathrm{~h}$. After cooling, deoxy-6-glucose $\left(0.4 \mathrm{mg} \cdot \mathrm{ml}^{-1}\right.$ in water $)$ was added as internal standard [21]. The sample was subsequently neutralised with $\mathrm{CaCO}_{3}$. The precipitate was removed by centrifugation and the supernatant evaporated to dryness. The sugars were then dissolved in $\mathrm{CH}_{3} \mathrm{OH}$ and the solution purified by centrifugation. After transferring the solution to another vessel, the solvent was evaporated under vacuum. The sugars were dissolved in pyridine containing $1 \%(\mathrm{v} / \mathrm{v})$ of $\mathrm{LiClO}_{4}$ and left $16 \mathrm{~h}$ at $60^{\circ} \mathrm{C}$ for anomer equilibration [27]. In both cases, they were silylated by BSTFA+TMCS (99:1) and analysed using a Perkin-Elmer AutoSystem XL GC (split injector, $240^{\circ} \mathrm{C}$; flame ionization detector (FID), $300^{\circ} \mathrm{C}$ ) with a fused silica capillary column (CPSil5CB, $25 \mathrm{~m}$ length, $0.25 \mathrm{~mm}$ i.d., $0.25 \mu \mathrm{m}$ film thickness) and helium as carrier gas. The GC was temperature programmed from 60 to $120^{\circ} \mathrm{C}$ at $30^{\circ} \mathrm{C} \cdot \mathrm{min}^{-1}$ (isothermal for $1 \mathrm{~min}$ ) and raised to $240^{\circ} \mathrm{C}$ at $5^{\circ} \mathrm{C} \cdot \mathrm{min}^{-1}$ and finally at $20^{\circ} \mathrm{C} \cdot \mathrm{min}^{-1}$ to $310^{\circ} \mathrm{C}$ and maintained at that temperature for $10 \mathrm{~min}$.

The second, consisting of the same procedure without $\mathrm{H}_{2} \mathrm{SO}_{4}(12 \mathrm{M})$ treatment, yielded only hemicellulose and free monomers. Consequently, the cellulose content was calculated by subtraction of the results obtained for the first experiment from those obtained for the second one. 
A mixture of ten monosaccharides (ribose, arabinose, xylose, rhamnose, fucose, glucose, mannose and galactose, lyxose and allose) was used as external standard for compound identification through peak retention times and for individual response coefficient determination. Analyses gave an analytical precision between 10 to $15 \%$ [22].

\subsection{Carbohydrate analysis by preparative thermochemolysis}

Each monosaccharide standard and cellulose $(10 \mathrm{mg}$ ) was placed in a ceramic boat after one hour moistening with $2 \mathrm{ml}$ of a $50 \%(\mathrm{w} / \mathrm{w})$ aqueous solution of tetramethylammonium hydroxide (TMAH). Each sample was transferred in a Pyrex ${ }^{\circledR}$ tube $(70 \mathrm{~cm}$ length, $3 \mathrm{~cm}$ i.d.) and heated at $400^{\circ} \mathrm{C}$ (30 min isothermal period) in a tubular furnace. Thermochemolysis

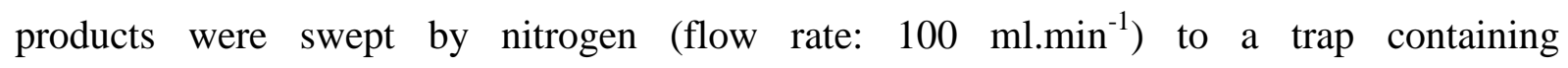
dichloromethane. After partial evaporation of the solvent under reduce pressure, trapped pyrolysates were analysed by GC-MS using a Trace GC Thermo Finnigan (split injector, $250^{\circ} \mathrm{C}$; FID, $300^{\circ} \mathrm{C}$ ) with a fused silica capillary column (Supelco Equity 5\%, $30 \mathrm{~m}$ length, $0.25 \mathrm{~mm}$ i.d., $0.25 \mu \mathrm{m}$ film thickness) and helium as carrier gas. The oven was initially kept at $60{ }^{\circ} \mathrm{C}$ for $1 \mathrm{~min}$, next it was heated at a rate of $5^{\circ} \mathrm{C} / \mathrm{min}$ to $300{ }^{\circ} \mathrm{C}$ and maintained at that temperature for $15 \mathrm{~min}$. The column was coupled to a Finnigan Trace MS quadrupole mass spectrometer (ionization energy $70 \mathrm{eV}$, mass range $\mathrm{m} / \mathrm{z} 45-600$, cycle time $1 \mathrm{~s}$ ). Peak integration for the permethylated deoxy aldonic acids was performed in the extracted ion chromatogram at $m / z, 129$ and at $m / z 173$ for those from cellulose. Thermochemolysis conditions for the analysis of carbohydrates in peat samples $(90 \mathrm{mg})$ are identical as above. The various products were identified on the basis of their GC retention times, their mass spectra (comparison with standards) and literature data. Semi-quantification was achieved by comparison of the peak area of a chosen permethylated isosaccharinic acid product specific to a type of carbohydrate with the peak area of the same permethylated isosaccharinic acids obtained after TMAH thermochemolysis of model compounds. Fig. 3 shows the extracted ion chromatograms at $m / z 129$ for an aldohexose (glucose), an aldopentose (xylose) and a 6deoxyhexoses (fucose). With the same approach, the abundance of cellulose was estimated following the mass fragment $\mathrm{m} / \mathrm{z}, 173$ response for each peat sample.

\section{Results}


Fig. 4 presents the depth distributions of carbohydrate concentrations within the peat core released both by hydrolysis with $\mathrm{H}_{2} \mathrm{SO}_{4}$ and TMAH thermochemolysis.

\section{$3.1 \mathrm{H}_{2} \mathrm{SO}_{4}$ hydrolysis}

The highest concentration of galactose is in the upper part of the acrotelm $\left(47 \mathrm{mg} \cdot \mathrm{g}^{-1}\right)$. Its concentration shows a distinct decrease in the water table zone (around $20 \mathrm{~cm}$ ) $\left(37 \mathrm{mg} \cdot \mathrm{g}^{-1}\right.$ ) before the concentrations increase to $46 \mathrm{mg} \cdot \mathrm{g}^{-1}$ at $30 \mathrm{~cm}$ before decreasing again to $22 \mathrm{mg} . \mathrm{g}^{-1}$ in the remaining part of the core. Gulose was not detected.

As for galactose, the concentration of glucose, mannose and allose are higher in the acroand mesotelm and lower in the catotelm. In the uppermost subsurface layer, concentration was $74 \mathrm{mg} \cdot \mathrm{g}^{-1}$ and increased to $88 \mathrm{mg} \cdot \mathrm{g}^{-1}$ at $15 \mathrm{~cm}$, then regularly decreased to around 55 $\mathrm{mg} \cdot \mathrm{g}^{-1}$ at $50 \mathrm{~cm}$.

The concentration of fucose shows a slight increase between the subsurface and the upper part of the mesotelm with values around ca. $4.2 \mathrm{mg} \cdot \mathrm{g}^{-1}$, before the concentration decreases to around $2 \mathrm{mg} \cdot \mathrm{g}^{-1}$ at the upper part of the catotelm. Finally an increase to $5 \mathrm{mg} \cdot \mathrm{g}^{-1}$ was observed in the deepest part of the core. The concentration of rhamnose shows relatively constant values of $12-14 \mathrm{mg} \cdot \mathrm{g}^{-1}$ in the acrotelm and mesotelm before decreasing to $7 \mathrm{mg} \cdot \mathrm{g}^{-1}$ in the catotelm.

The aldopentoses (mainly xylose and arabinose) content slightly increases from the subsurface $\left(55 \mathrm{mg} \cdot \mathrm{g}^{-1}\right)$ to the end of the acrotelm $\left(70 \mathrm{mg} \cdot \mathrm{g}^{-1}\right)$ before decreasing in the mesotelm $\left(54 \mathrm{mg} \cdot \mathrm{g}^{-1}\right)$ and then decreasing with depth (from 72 to $37 \mathrm{mg} \cdot \mathrm{g}^{-1}$ ) in the lower anoxic part.

Cellulose concentration increases through the acrotelm (from 124 to $161 \mathrm{mg} \cdot \mathrm{g}^{-1}$ ) before strongly decreasing in the uppermost mesotelm to $66 \mathrm{mg} \cdot \mathrm{g}^{-1}$ and dropping to relatively constant values around $105 \mathrm{mg} \cdot \mathrm{g}^{-1}$ in the catotelm.

\subsection{TMAH Thermochemolysis}

After TMAH thermochemolysis, series of permethylated deoxy aldonic acids were identified in the six peat samples. In all samples, the main permethylated deoxy aldonic acids observed arose from cellulose and from free forms of glucose (and mannose/allose). Free forms of aldopentoses, 6-deoxyhexoses and galactose (with gulose and idose) were detected in lower amounts (Fig. 4). 
In the acrotelm (0 to $20 \mathrm{~cm}$ ), all the permethylated deoxy aldonic acids products of free carbohydrates decrease with depth (from 12.0 to $6.7 \mathrm{mg} . \mathrm{g}^{-1}$ for aldopentoses, from 22.8 to $11.4 \mathrm{mg} . \mathrm{g}^{-1}$ for glucose, mannose and allose, from 4.4 to $1.8 \mathrm{mg} \cdot \mathrm{g}^{-1}$ for galactose, from 1.0 to $0.7 \mathrm{mg} \cdot \mathrm{g}^{-1}$ for rhamnose and from 0.9 to $0.5 \mathrm{mg} \cdot \mathrm{g}^{-1}$ for fucose). Cellulose concentration decreases also with depth from 546 to $211 \mathrm{mg} \cdot \mathrm{g}^{-1}$.

Through the mesotelm, the concentration of aldopentoses, rhamnose and fucose continues to decrease to values around 5.0,0.4 and $0.3 \mathrm{mg}^{-\mathrm{g}^{-1}}$ respectively. Glucose (with mannose and allose), galactose and cellulose concentrations drop in the uppermost mesotelm and decrease

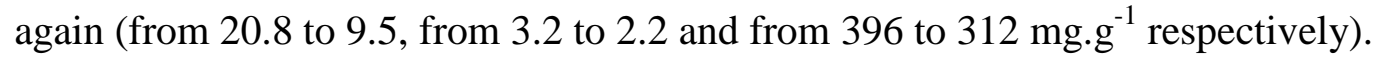

All the concentrations of free carbohydrates show a distinct increase in the deepest part of the peat core (the catotelm) to values higher than in the upper part of the acrotelm. The concentration of cellulose increases in lower proportion up to ca. 447 mg.g ${ }^{-1}$ (Fig. 4).

\section{Discussion}

Acid hydrolysis carbohydrates showed high amounts in agreement with previous works [22]. Amounts of carbohydrates, and especially of hemicellulose sugars content, are almost constant in the first $20 \mathrm{~cm}$ denoting a high preservation of these biopolymers (Fig. 4). With depth, the substantial variations in cellulose sugars, that are the structural sugars of plant tissues, reflect that this polymer is a prime target of degradation.

Carbohydrates monomers could also be used to infer vegetation communities changes. As an example, some sugars such as galactose and rhamnose are considered as mosses indicators $[22,25]$ whereas arabinose and xylose (aldopentoses) are considered as sedges indicators [8, 21-24]. Therefore, carbohydrates patterns with depth tended to indicate a decrease of mosses contribution and therefore, an enhanced sedges contribution to organic matter inputs with increasing age.

Similar distribution was not apparent for the TMAH results. With thermochemolysis, amounts of all the analysed free carbohydrate types and cellulose decrease with depth in the acrotelm before increasing in the catotelm. Poor agreement between the two methods occurs because of inherent differences in chemolytic mechanisms, which resulted in bias in detection of carbohydrates pools. Specifically, whereas the acid hydrolysis method is a classical way for the analysis of almost all types of carbohydrates, the TMAH thermochemolysis allows the specific analyses of free (or terminal) carbohydrates. As a consequence, amounts of non- 
cellulosic carbohydrates obtained by TMAH thermochemolysis are lower than those obtained by the acid hydrolysis method.

Contrary to acid hydrolysis, TMAH thermochemolysis is able to cleave common ester and ether bonds and to methylate acidic functional groups. Hydrolysable ester and labile ether bonds are present in acid-insoluble substances such as biopolymers (i.e. lignin, cutins, waxes or tannins) and products formed during decomposition (i.e. humic substances) [28-29]. Because of the capability of TMAH thermochemolysis to cleave macromolecular structures (i.e. cleavage of $\beta-\mathrm{O}-4$ bonds in lignin [30-32]), it allows the analyses of compounds entrapped in macromolecular network [12]. It results in the possible recovery of entrapped carbohydrates and consequently in a greater cellulosic carbohydrates yield than for acid hydrolysis.

In the oxic acrotelm, free carbohydrates and cellulose decreased. This might be link with decomposition dynamic occurring in the oxic acrotelm. With depth, organic matter was more decomposed. Therefore, deeper peat layers present lower yields of decomposable organic matter than in the upper part where fresh plant inputs occurred. In the oxic acrotelm, TMAH thermochemolysis of carbohydrates might thus reflected a decrease of decomposability potential of organic matter with depth. Below the oxic acrotelm, the mesotelm is considered as the compartment where water-level changes [33] and were peat decomposition might be enhanced [34]. At this depth, cellulose, glucose and galactose presented enhanced amounts at ca. $20 \mathrm{~cm}$ depth. Therefore, TMAH thermochemolysis of carbohydrates might reflect this enhanced decomposition dynamic of the mesotelm by the way of an increased of available free carbohydrates and cellulose amounts under microbial activity. Finally in the lower anoxic part, i.e. the catotelm, simple carbohydrates and cellulose amounts increased. The catotelm is considered as the deeper peat compartment characterised by low decomposition processes and by the accumulation of refractory compounds. Among these refractory biopolymers, lignin forms a resistant shield around cellulose to form lignocellulose in plant cell walls [35-36]. As also suggested by the acid analysis of sugars, the increase with depth of cellulose analysed by TMAH thermochemolysis could indicate therefore a greater contribution from vascular plants (i.e. Eriophorum spp.) with increasing age. Peatland evolution involves a number of dynamic stages characterised by specific plant communities, changing from a fen characterised by the predominance of Cyperaceae spp. to a raised bog with vegetation dominated by Sphagnum spp. communities [37]. Our results could thus document this typical change in peatland evolution (from sedges in the bottom to Sphagnum spp. in the top). 
On the other hand, a micro-morphological characterisation of the same peat core [38] has shown that the relative abundance of well-preserved tissues decreased with increasing depth (from 66 to 11\%) while mucilage contents (partly derived from in situ microbial syntheses [39] increased (from 7 to $30 \%$ ). In addition, the relative amounts of the acid-insoluble organic matters increase gradually as the decomposition proceeds [40]. Therefore, the increased amounts of refractory neosynthetic organic compounds (the so-called humic substances) with depth could be another way to explain the enhanced amount of carbohydrates obtained by TMAH thermochemolysis in the catotelm. In such a case, refractory neosynthetic organic compounds might act as a trap for carbohydrates. Because of the lack of complementary information, we can not argue if the enhanced carbohydrates amounts were due to past vegetation changes and/or to past humification processes. Combined with other analyses, TMAH thermochemolysis of carbohydrates might be considered as a useful tool to provide information about recent organic matter decomposition but also on past depositional environments.

\section{Conclusion}

When compared with the widely used acid hydrolysis developed for carbohydrates analysis, the application of TMAH thermochemolysis to our sediment samples did not analyse hemicellulosic carbohydrates and discriminate each individual carbohydrates. However, TMAH thermochemolysis allows the analysis of a cellulose pool hidden to acid hydrolysis and the specific analysis of free and terminal carbohydrates. As a consequence, we caution against making simple direct comparisons of thermochemolysis data with data generated from acid hydrolysis because of the different mechanisms involved in each process. Nevertheless, and because of their differences, they would be viewed and used as pertinent complementary methods for the analysis of carbohydrates in complex environmental systems.

\section{References}

[1] W. Amelung, M.V. Cheshire, G. Guggenberger, Determination of neutral and acidic sugars in soil by capillary gas liquid chromatography after trifluoroacetic acid hydrolysis, Soil Biol. Biochem. 28 (1996) 1631-1639. 
[2] J.E. Modzeleski, W.A. Laurie, B. Nagy, Carbohydrates from Santa Barbara Basin sediments: gas chromatographic mass spectrometric analysis of trimethylsilyl derivatives, Geochim. Cosmochim. Acta 35 (1971) 825-838.

[3] G.L. Cowie, J.I. Hedges, Carbohydrate sources in a coastal marine environment, Geochim. Cosmochim. Acta 48 (1984) 2075-2087.

[4] S. Hu, D.C. Coleman, M.H. Beare, P.F. Hendrix, Soil carbohydrates in aggrading and degrading agroecosystems: influences of fungi and aggregates, Agric. Ecosyst. Environ. 54 (1995) 77-88.

[5] N. Koivula, K. Hänninen, Concentrations of monosaccharides in humic substances in the early stages of humification, Chemosphere 44 (2001) 271-279.

[6] P. Rovira, V.R. Vallejo, Labile, recalcitrant, and inert organic matter in Mediterranean forest soils, Soil Biol. Biochem. 39 (2007) 202-215.

[7] S. Ogier, J.-R. Disnar, P. Albéric, G. Bourdier, Neutral carbohydrate geochemistry of particulate material (trap and core sediments) in an eutrophic lake (Aydat, France), Org. Geochem. 32 (2001) 151-162.

[8] S. Bourdon, F. Laggoun-Défarge, J.-R. Disnar, O. Maman, B. Guillet, S. Derenne, C. Largeau, Organic matter sources and early diagenetic degradation in a tropical peaty marsh (Tritivakely, Madagascar), Org. Geochem. 31 (2000) 421-438.

[9] C. Rumpel, M.-F. Dignac, Chromatographic analysis of monosaccharides in a forest soil profile: Analysis by gas chromatography after trifluoroacetic acid hydrolysis and reductionacetylation, Soil Biol. Biochem. 38 (2006) 1478-1481.

[10] S. Spielvogel, J. Prietzel, I. Kögel-Knabner, Changes of lignin phenol and neutral sugar pools in different soil types of a high-elevation forest ecosystem 25 years after forest dieback Soil Biol. Biochem. 39 (2007) 655-668.

[11] F. Shadkami, R. Helleur, Recent applications in analytical thermochemolysis, J. Anal. Appl. Pyrol. 89 (2010) 2-16.

[12] L. Grasset, A. Amblès, Structural study of soil humic acids and humin using a new preparative thermochemolysis technique, J. Anal. Appl. Pyrol. 47 (1998) 1-12.

[13] D. Fabbri, R. Helleur, Characterisation of the tetramethylammonium hydroxide thermochemolysis products of carbohydrates, J. Anal. Appl. Pyrol. 49 (1999) 277-293.

[14] L. Grasset, P. Rovira, A. Amblès, TMAH-preparative thermochemolysis for the characterization of organic matter in densimetric fractions of a Mediterranean forest soil, $\mathrm{J}$. Anal. Appl. Pyrol. 1-2 (2009) 435-441. 
[15] D.J. Clifford, D.M. Carson, D.E. McKinney, M. Bortiatynski, P.G. Hatcher, A new rapid technique for the characterization of lignin in vascular plants: thermochemolysis with tetramethylammonium hydroxide (TMAH), Org. Geochem. 23 (1995) 169-175.

[16] A. Gauthier, S. Derenne, C. Largeau, L. Dupont, E. Guillon, J. Dumonceau, M. Aplincourt, Comparative study of ligno-cellulosic material from wheat straw and of pure and mixed standard compounds via solid state ${ }^{13} \mathrm{C}$ NMR spectroscopy, conventional pyrolysis and TMAH thermochemolysis, J. Anal. Appl. Pyrol. 67 (2003) 277-293.

[17] B. Chefetz, Y. Chen, C.E. Clapp, P.G. Hatcher, Characterization of organic matter in soils by thermochemolysis using tetramethylammonium hydroxide (TMAH), Soil Sci. Soc. Am. J. 64 (2000) 583-589.

[18] C. Schwarzinger, On the mechanism of thermally assisted hydrolysis and methylation of carbohydrates: the contribution of aldol and retroaldol reactions, J. Anal. Appl. Pyrol. 68-69 (2003) 137-149.

[19] I. Tanczos, C. Schwarzinger, H. Schmidt, J. Balla, THM-GC/MS analysis of model uronic acids of pectin and hemicellulose, J. Anal. Appl. Pyrol. 68-69 (2003) 151-162.

[20] J. Bleton, P. Mejanelle, J. Sansoulet, S. Goursaud, A. Tchapla, Characterization of neutral sugars and uronic acids after methanolysis and trimethyl-silylation for recognition of plant gums, J. Chromatogr. A 720 (1996) 27-49.

[21] R.J. Wicks, M.A. Moran, L.J. Pittman, R.E. Hodson, Carbohydrate signatures of aquatic macrophytes and their dissolved degradation products as determined by a sensitive highperformance ion chromatography method, Appl. Environ. Microbiol. 57 (1991) 3135-3143.

[22] L. Comont, F. Laggoun-Défarge, J.-R. Disnar, Evolution of organic matter indicators in response to major environmental changes: the case of a formerly cutover peatbog (Le Russey, Jura Mountains, France), Org. Geochem. 37 (2006) 1736-1751.

[23] M.E.C. Moers, J.J. Boon, J.W. De Leeuw, M. Baas, P.A. Schenck, Carbohydrate speciation and Py-MS mapping of peat samples from a subtropical open marsh environment, Geochim. Cosmochim. Acta 53 (1989) 2011-2021.

[24] M.E.C. Moers, M. Baas, J.W. De Leeuw, J.J. Boon, P.A. Schenck, Occurrence and origin of carbohydrates in peat samples from a red mangrove environment as reflected by abundances of neutral monosaccharides, Geochim. Cosmochim. Acta 54 (1990) 2463-2472.

[25] Z.A. Popper and S.C. Fry, Primary cell wall composition of bryophytes and charophytes, Ann. Bot. 91 (2003) 1-12.

[26] V.E.J. Jassey, G. Chiapusio, D. Gilbert, A. Buttler, M.-L. Toussaint, P. Binet., Experimental climate effect on seasonal variability of polyphenol/phenoloxidase interplay 
along a narrow fen-bog gradient in Sphagnum fallax, Global Change Biology (2011) DOI 10.1111/j1365-3486-2011-02437-x.

[27] P.O. Bethge, C. Holmström, S. Juhlin, Quantitative gas chromatography of mixtures of simple sugars. Svensk Papperst. 69 (1966) 60-63.

[28] W. Zech, M.-B. Johansson, L. Haumaier, R.L. Malcolm, CPMAS ${ }^{13}$ C NMR and IR spectra of spruce and pine litter and of the Klason lignin fraction at different stages of decomposition, Z. Pflanzenern. Bodenk. 150 (1987) 262-265.

[29] C.M. Preston, J.R. Nault, J.A. Trofymow, Chemical Changes During 6 Years of Decomposition of 11 Litters in Some Canadian Forest Sites. Part $2 .{ }^{13} \mathrm{C}$ Abundance, SolidState ${ }^{13}$ C NMR Spectroscopy and the Meaning of "Lignin", Ecosystems 12 (2009) 1078-1102. [30] J.M. Challinor, Characterisation of wood by pyrolysis derivatisation-gas chromatography/mass spectrometry, J. Anal. Appl. Pyrol 35 (1995) 93-107.

[31] P.G. Hatcher, M.A. Nanny, R.D. Minard, S.D. Dible, D.M. Carson, Comparison of two thermochemolytic methods for the analysis of lignin in decomposing gymnosperm wood: the $\mathrm{CuO}$ oxidation method and the method of thermochemolysis with tetramethylammonium hydroxide (TMAH), Org. Geochem. 23 (1995), 881-888.

[32] L.A. Wysocki, T.R. Filley, T.S. Bianchi, Comparison of two methods for the analysis of lignin in marine sediments: $\mathrm{CuO}$ oxidation versus tetramethylammonium hydroxide (TMAH) thermochemolysis, Org. Geochem. 39 (2008) 1454-1461.

[33] R.S. Clymo, C.L. Bryant, Diffusion and mass flow of dissolved carbon dioxide, methane, and dissolved organic carbon in a 7-m deep raised peat bog, Geochim. Cosmochim. Acta 72 (2008) 2048-2066.

[34] A. Haraguchi, C. Hasegawa, A. Hirayama, H. Kojima, Decomposition activity of peat soils in geogenous mires in Sasakami, central Japan, Eur. J. Soil Biol. 39 (2003) 191-196.

[35] T. Osono, Ecology of ligninolytic fungi associated with leaf litter decomposition, Ecol. Res. 22 (2007) 955-974.

[36] R.C. Cooke, A.D.M. Whipps, Ecophysiology of fungi, Blackwell, Oxford, 1993.

[37] O. Manneville, V. Vergne, O., Villepoux, Le monde des tourbières et des marais : France, Suisse, Belgique et Luxembourg,. Delachaux et Niestlé, Paris-Lausanne, 1999.

[38] F. Delarue, F. Laggoun-Défarge, J.R. Disnar, N. Lottier, S. Gogo, Organic matter sources and decay assessment in a Sphagnum-dominated peatland (Le Forbonnet, Jura Mountains, France): impact of moisture conditions, Biogeochem. (2011) DOI 10.1007/s10533-010-94100 
[39] F. Laggoun-Défarge, S. Bourdon, C. Chenu, Etude des transformations morphologiques précoces des tissues végétaux de tourbe. Apport du marquage histochimique en MET et du cryo-MEB haute resolution, in: F. Elsass F, A.M. Jaunet (Eds.), Structure et ultrastructure des sols et des organismes vivants, INRA, Paris, 1999, pp. 169-182.

[40] C. McClaugherty, B. Berg, Cellulose, lignin and nitrogen concentration as rate regulating factors in late stages of forest litter decomposition, Pedobiologia 30 (1987) 101-112. 
Fig. 1: Mechanism proposed by Fabbri and Helleur (1999) [13] of the formation of methylated saccharinic acids from the TMAH thermochemolysis of glucose.

Fig. 2: Peat core and depths of sampling.

Fig. 3: Extracted Ion Chromatograms at m/z 129 of permethylated saccharinic acids obtained after TMAH thermochemolysis of glucose (a), xylose (b) and fucose (c) and at $\mathrm{m} / \mathrm{z}$ 173 of permethylated saccharinic acids obtained after TMAH thermochemolysis of cellulose

(d). Peaks in gray are peaks corresponding to permethylated saccharinic acids used for quantification.

Fig. 4 : Depth distributions of carbohydrate concentrations within the peat core released after $\mathrm{H}_{2} \mathrm{SO}_{4}$ hydrolysis (up) and TMAH thermochemolysis (down) (in mg/g of dry sample). 
<smiles>O=C[C@H](O)[C@@H](O)[C@H](O)[C@H](O)CO</smiles>
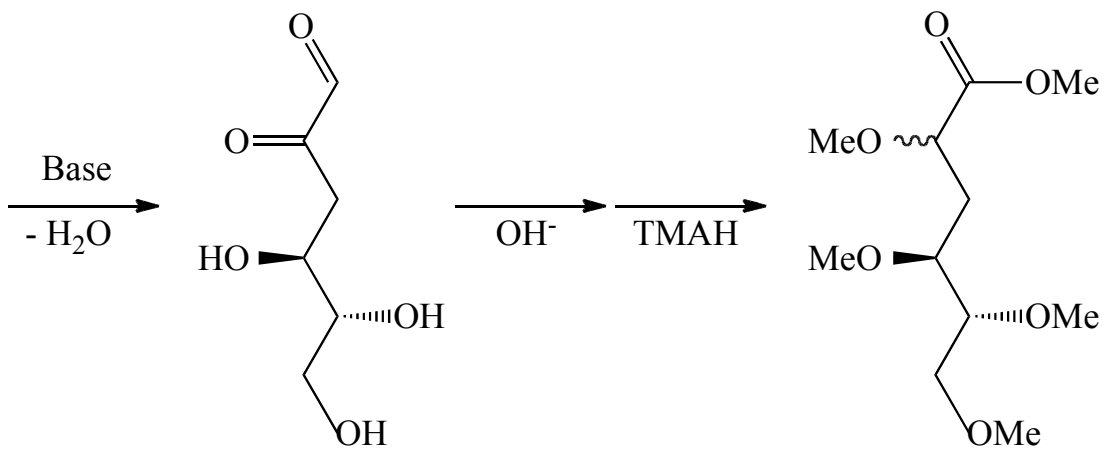

Page 15 of 18 


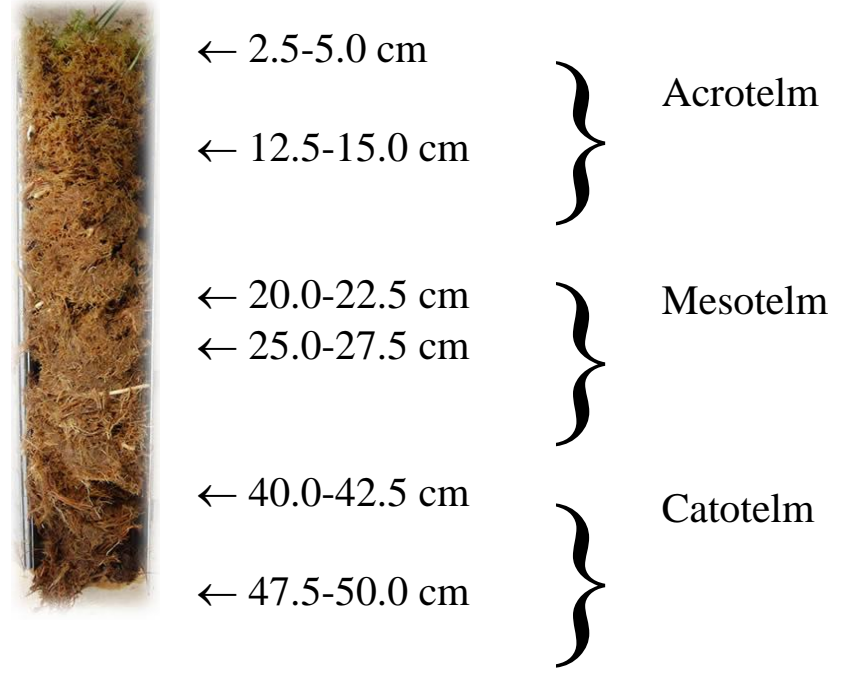



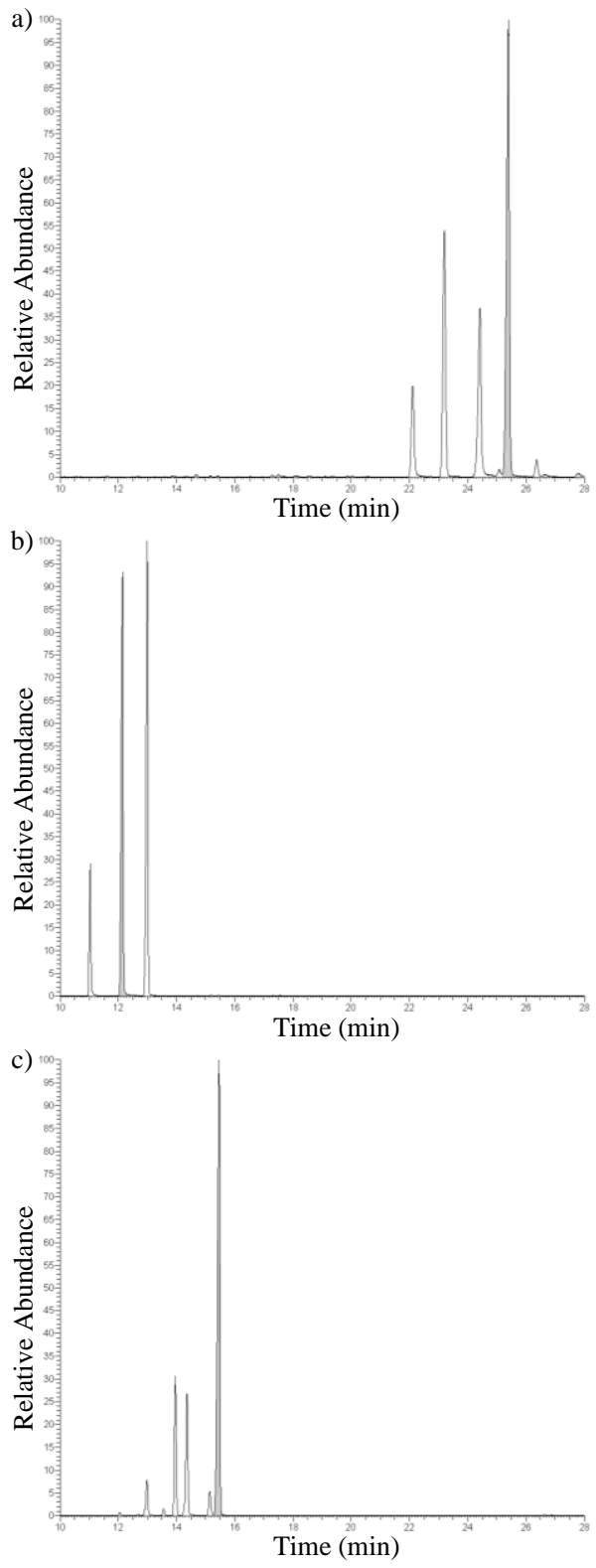

d)

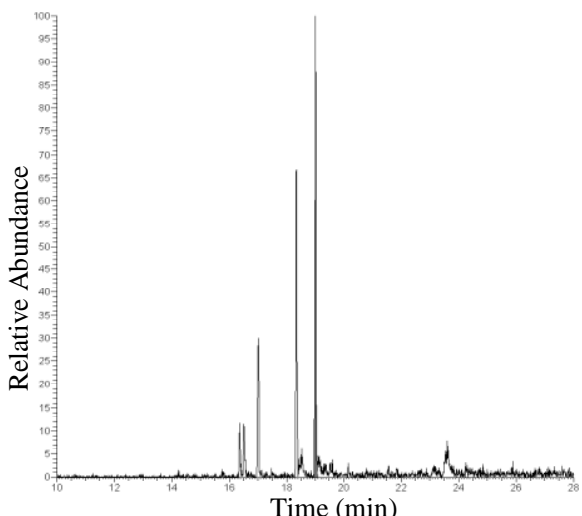

Page 17 of 18 
Cellulose Aldopentoses Rhamnose Fucose
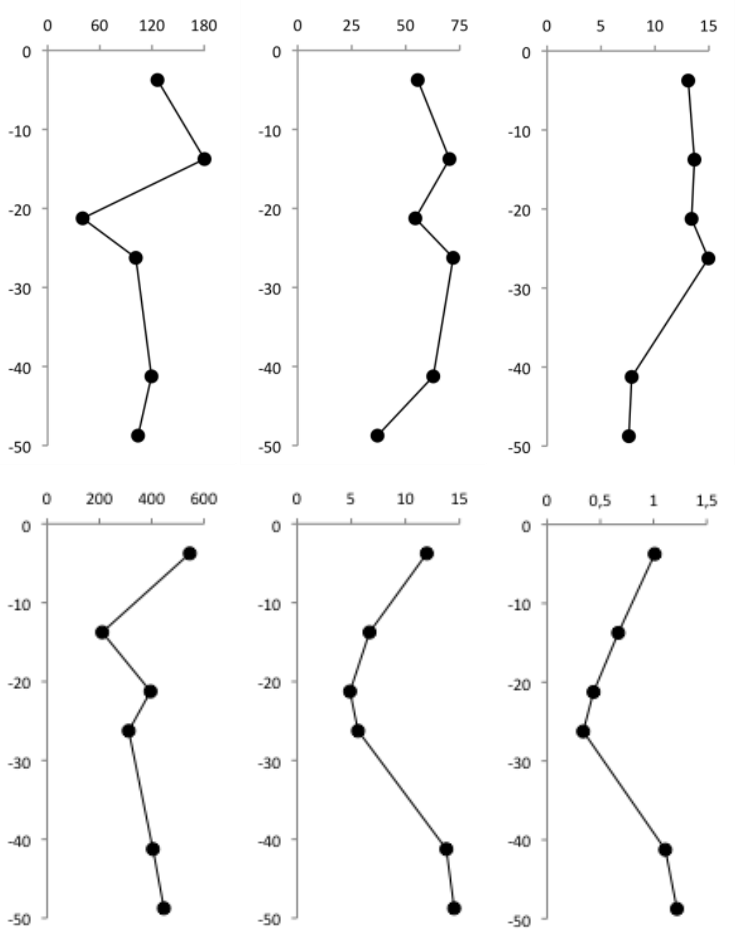

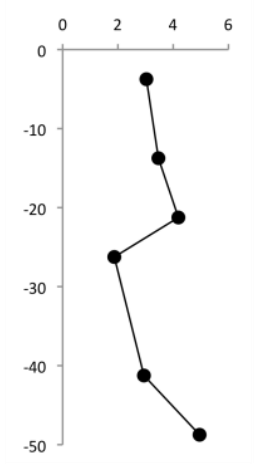

Glucose

Mannose, Allose Galactose
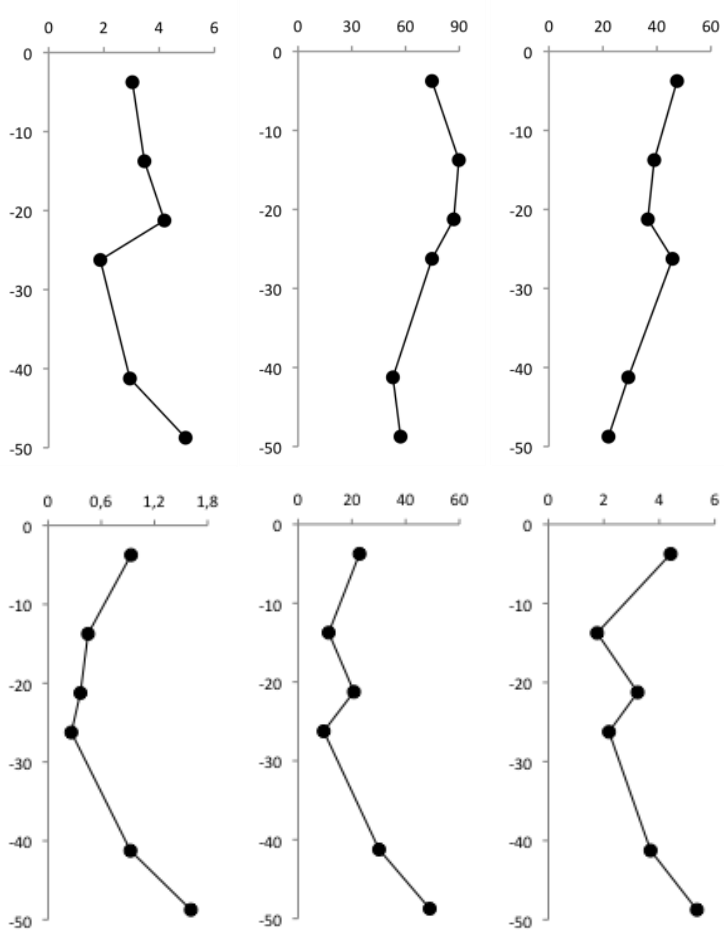

Page 18 of 18 